Spatial Divisions of Labour 
Also by Doreen Massey

CAPITAL AND LAND (with Alejandrina Catalano)

THE GEOGRAPHY OF INDUSTRIAL REORGANISATION (with Richard Meegan)

THE ANATOMY OF JOB LOSS (with Richard Meegan)

GEOGRAPHY MATTERS! (edited with John Allen)

POLITICS AND METHOD (edited with Richard Meegan)

THE ECONOMY IN QUESTION (edited with John Allen)

UNEVEN RE-DEVELOPMENT (edited with John Allen)

HIGH-TECH FANTASIES (with Paul Quintas and David Wield)

SPACE, PLACE AND GENDER 


\section{Spatial Divisions of Labour}

\section{Social Structures and the Geography of Production}

SECOND EDITION

Doreen Massey 
(C) Doreen Massey 1984, 1995

All rights reserved. No reproduction, copy or transmission of this publication may be made without written permission.

No paragraph of this publication may be reproduced, copied or transmitted save with written permission or in accordance with the provisions of the Copyright, Designs and Patents Act 1988, or under the terms of any licence permitting limited copying issued by the Copyright Licensing Agency, 90 Tottenham Court Road, London WIP 9HE.

Any person who does any unauthorised act in relation to this publication may be liable to criminal prosecution and civil claims for damages.

First edition 1984

Reprinted 1985, 1987, 1990

Second edition 1995

Published by

MACMILLAN PRESS LTD

Houndmills, Basingstoke, Hampshire RG21 2XS

and London

Companies and representatives

throughout the world

ISBN 978-0-333-59494-0

ISBN 978-1-349-24059-3 (eBook)

DOI 10.1007/978-1-349-24059-3

A catalogue record for this book is available from the British Library.

This book is printed on paper suitable for recycling and made from fully managed and sustained forest sources. Logging, pulping and manufacturing processes are expected to conform to the environmental regulations of the country of origin.

$\begin{array}{rrrrrrrrrr}10 & 9 & 8 & 7 & 6 & 5 & 4 & 3 & 2 & 1 \\ 04 & 03 & 02 & 01 & 00 & 99 & 98 & 97 & 96 & 95\end{array}$

Copy-edited and typeset by Povey-Edmondson Okehampton and Rochdale, England 


\section{FOR}

NANCY AND JACK

with many thanks

and much love 


\section{Contents}

Preface to the First Edition

$\mathrm{x}$

Preface to the Second Edition xii

List of Tables xiv

List of Figures $\quad \mathrm{xv}$

List of Abbreviations $\quad$ xvi

1. The Issues 1

2. Social Relations and Spatial Organisation 12

$\begin{array}{lll}2.1 \text { The debate } & 12\end{array}$

$\begin{array}{ll}2.2 \text { Characterising capital } & 17\end{array}$

$\begin{array}{ll}\text { The problem } & 17\end{array}$

Place in economic structure $\quad 19$

Contrasts in labour process $\quad 22$

The organisational structure of capital 25

Some conclusions 28

2.3 Social structures and capitalist relations of production $\quad 30$

A framework $\quad 30$

Elaborations $\quad 39$

Reflections 43 2.4 The social and the spatial: an impossible
dichotomy

Geography matters $\quad 49$

Places and politics $\quad 56$

2.5 An example 61

3. Uneven Development and Spatial Structures 65

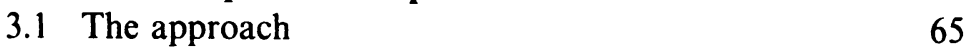

3.2 Spatial structures of capitalist production $\quad 68$

Conceptualising the spatial organisation of
production

Some issues $\quad 80$

An example $\quad 90$

3.3 Spatial structures of production and geographical inequality 
Not two-dimensional patterns, but underlying relations

Spatial structures and social structures

3.4 The uniqueness of place

4. Some Changing Spatial Structures in the United Kingdom

4.1 Setting the scene

The inheritance: social and spatial

The fifties: a wasted decade

The cracks begin to show

4.2 Electronics and instruments industries

The character of the industry

Labour as a 'location factor': a social process

Spatial structures of large firms

Spatial structures of small firms

4.3 Clothing and footwear

The character of the industry: increasing pressures

The search for new labour: two different strategies

Spatial structures of big firms

The impact on national geography $\quad 164$

Methodological reflections 166

4.4 Services

The industry: what are 'services' anyway?

Self-employment and family enterprises

Other consumer services: private capital and the

State

Producer services

An emerging spatial structure

5. The Effects on Local Areas: Class and Gender Relations

5.1 The general and the unique

5.2 The coalfield areas

The pre-existing structure

The impact, or 'the combination of layers'

5.3 A different kind of 'periphery': the case of Cornwall

The pre-existing structure

The impact, or 'the combination of layers' 
6. Class, Politics and the Geography of Employment 226

6.1 Spatial structures and spatial divisions of labour 226

6.2 Uneven development and national politics 228

Modernisation $\quad 228$

Muddling through $\quad 245$

Monetarism 255

6.3 Changes in the geography of class relations 264

The geography of the ownership of production $\quad 264$

White-collar hierarchies $\quad 276$

Social and spatial restructuring in the working class

281

7. The Reproduction of Inequality: A Question of Politics 287

8. Reflections on Debates over a Decade 296

8.1 Themes 296

8.2 Marxism and the analysis of capitalism 297

Capitalism $\quad 297$

Structures, laws and tendencies 301

Flows of value and the analysis of class relations $\quad 307$

8.3 Explanation 311

Outcomes and causes $\quad 312$

Articulation/thinking in terms of relations $\quad 315$

A final note on variety and specificity 324

8.4 The conceptualisation of space 326

The geography of the relations of production $\quad 326$

Broadening the analysis $\quad 332$

A concluding note on spatial structures $\quad 339$

8.5 Gender and feminism 341

Recapitulation of themes $\quad 342$

A question of conceptual approach 349

Notes and References $\quad 355$

Bibliography 368

Author Index $\quad 382$

Subject Index 386 


\section{Preface to the First Edition}

This book has been a long time in the making. It began life as a contribution to a debate within the branch of geography known as 'industrial location theory' - as what I hoped would be a trenchant critique of all, or pretty much all, that had gone before, together with a second half which would present 'an alternative approach'. A number of things have happened in the period since then. I got bored with the critique. The second 'half' became the length of a book in itself, and it also changed its nature. From being a schematic outline it became increasingly grounded in what was going on in Britain and in other advanced capitalist countries.

But more than anything else I became increasingly convinced of the importance of the issues involved and of the fact that they should have a wider audience. My basic aim had been to link the geography of industry and employment to the wider, and underlying, structures of society. And one of the things I do in the book is present an approach which, I hope, makes that possible. The initial intention, in other words, was to start from the characteristics of economy and society, and proceed to explain their geography. But the more I got involved in the subject, the more it seemed that the process was not just one way. It is also the case - I would argue that understanding geographical organisation is fundamental to understanding an economy and a society. The geography of a society makes a difference to the way it works.

If this is true analytically, it is also true politically. For there to be any hope of altering the fundamentally unequal geography of British economy and society (and that of other capitalist countries, too), a politics is necessary which links questions of geographical distribution to those of social and economic organisation. Effectively to confront the spatial inequality in Britain today means taking on much the same battles - and much the same social strata as is necessary to win any wider progressive change. But it is equally true that any wider national political strategy must be sensitive to the variations in economic structure, in occupations, in political tradition and in the fabric of day-to-day life which exist between different parts of the country. 
I have had a lot of help and support during the production of this book. Most of the book was written while I was the SSRC Fellow in Industrial Location Research, and I should like to thank the SSRC and its staff. The development of the ideas and arguments has been aided and stimulated by many friends and colleagues over a number of years. It would be impossible to mention everyone by name. What has been best about the process has been the gradual development of a practice which at least tries to argue without scoring points, and to criticise by being constructive. For their help, particularly in the final stages, however, I should like to thank Michael Ball and Huw Beynon, who read the manuscript, Nancy Massey for typing it magnificently, and a number of times, Richard Meegan, my co-worker for many eventful years, and Ron Martin.

Faculty of Social Sciences

Doreen Massey

The Open University

Milton Keynes, England 


\section{Preface to the Second Edition}

When the idea of a second edition of Spatial Divisions of Labour was first suggested to me, some time ago, I was reluctant initially to take it up. Above all I was unsure of the form which it should take.

The first edition of the book was stimulated in part by empirical changes, by the great shifts which began to take place in regional (i.e. sub-national) economic and social geographies in the first world, from about the middle years of the 1960s. Such changes were important - they affected the lives of people in cities and regions across large parts of the world. But the message I wanted to draw from those changes was most importantly theoretical. The idea was to communicate $a$ way of understanding uneven geographical development, rather than to advance an interpretation of the shape of the world at some particular moment. The latter was important too but it was, as much as anything, a vehicle for a more general message. The arguments concerned, above all, the way in which we conceptualise economic and to some extent more general social space, about how we understand the differences and structures of inequality within it, and about how we might begin to think of the economic identities of unique places.

These issues, it seems to me, remain important. Much of the argument of Spatial Divisions of Labour has been widely accepted among geographers. But there remain ambiguities and (as they seem to me!) misunderstandings. Moreover, since the time of the first edition there has been wide-ranging debate, discussion, not to say controversy, in part sparked by the book itself, in part originating elsewhere but within which the book has nevertheless become embroiled. As Ann Markusen and Ron Martin point out in their recent assessments of the book and its career (Progress in Human Geography, 1993), some of its ways of arguing foreshadowed issues only now emerging more broadly on to the agenda of intellectual debate. They are, moreover, issues which go way beyond the discipline of geography to engage with currents of argument about spatiality, location and place, about uniqueness, contingency and modes of theorising - now preoccupying a wide range of the human sciences. 
It therefore seemed appropriate for a second edition to be focused on these debates, and on an exploration of the theoretical argument of the book in the context of some of the discussions of which over the last decade it has been part and in the light of subsequent theoretical developments. The body of the book, from Chapter 2 to the original 'Postscript', therefore remains unchanged except for the correction of some minor typographical errors. However, both the first and last chapters of this edition are new and, as well as considering recent changes in the nature and form of uneven development, most centrally take on this task of making more explicit the key theoretical arguments and methodological stances of the book and of setting them in the context of wider current debate. The new first chapter reassesses the purpose and broad form of the book and pulls out the issues which are most important and which have become foci of subsequent debate. The new last chapter provides a detailed commentary on the text under these major headings. It is hoped that this will clarify some of the book's positions and intentions and set them in a wider context, that in particular it will make the book more helpful for teaching purposes (by tracing threads of argument as they appear - as theoretical statement or in concrete use - in different parts of the book), and that it will provoke yet further discussion on issues which remain of central importance.

I should like to thank my publisher Steven Kennedy for goading me into this, and for his continued advice and cheerful encouragement. I should also like to thank John Allen, Allan Cochrane and Andrew Sayer for helpful comments and much discussion. In the ten years since I wrote the first edition of Spatial Divisions of Labour I have been working at the Open University. It is a place which has a perhaps unique and certainly very collaborative and cooperative way of working. My colleagues there, most particularly in Geography, have been a constant source of new ideas and of intellectual stimulation, and I am grateful for that. I should further like to thank Doreen Warwick and Margaret Charters, also of the Open University, for typing the material for this second edition. 


\section{List of Tables}

4.1 Changes in the sectoral distribution of employers and self-employed within services, between 1961 and $1975 \quad 171$

4.2 Self-employment as a percentage of total sectoral employment, by region, in 1975

4.3 The percentage of UK research establishments in the south-east of England, 1968

4.4 Employment-based location quotients for office occupations, 1971 (England and Wales)

5.1 Industrial jobs created in Wales, 1977

5.2 Economic activity rates in industrial south Wales and Great Britain

5.3 Age-specific activity rates for men, 1971: a comparison between regions

5.4 Workers living in Rhondda in 1966 but working elsewhere

6.1 Some employment characteristics of the modernisation period

6.2 Some employment characteristics of the mid-1970s

A.1 Class composition and class self-image of mining and resort areas, 1970 (in percentages)

A.2 Partisan self-image by class in mining areas and resorts, 1970 (in percentages) 


\section{List of Figures}

2.1 A basic framework

3.1 Managerial hierarchies and relations of ownership and possession: a basic shape

3.2 The division of labour in production in parts of electronics

3.3 Three locations showing three different spatial structures

3.4 Three different part-process possibilities

3.5 Occupations, relations and social classes

5.1 The acclimatisation of labour

$5.2 \ldots$ and the acclimatisation of management

6.1 The role of regional policy in the National Plan

6.2 Competition between areas 


\section{List of Abbreviations}

AUEW Amalgamated Union of Engineering Workers

BLMC British Leyland Motor Corporation

BSC British Steel Corporation

CBI Confederation of British Industry

CDP Community Development Project

CIDA Cornwall Industrial Development Association

CPSA Civil and Public Services Association

CSO Central Statistical Office

DEA Department of Economic Affairs

EAG Economists Advisory Group

EC European Community

ECSC European Coal and Steel Community

EDC Economic Development Council

EEC European Economic Community

ESRC Economic and Social Research Council

HMSO Her Majesty's Stationery Office

IDC Industrial Development Certificate

ILAG Inquiry into Location Attitudes Group

IMF International Monetary Fund

IRC Industrial Reorganisation Corporation

LOB Location of Offices Bureau

MP Member of Parliament

NALGO National Association of Local Government

Officers

NCB National Coal Board

NEB National Enterprise Board

NEDO National Economic Development Office

NUFLAT National Union of Footwear, Leather and

Allied Trades

NUGMW National Union of General and Municipal

Workers

NUM National Union of Mineworkers

NUTGW National Union of Tailors and Garment

Workers

OECD Organisation of Economic Cooperation and

Development 


$\begin{array}{ll}\text { PBR } & \text { Payment By Results } \\ \text { REP } & \text { Regional Employment Premium } \\ \text { ROSE } & \text { Rest of South East } \\ \text { SET } & \text { Selective Employment Tax } \\ \text { SIC } & \text { Standard Industrial Classification } \\ \text { SSRC } & \text { Social Science Research Council } \\ \text { TGWU } & \text { Transport and General Workers' Union } \\ \text { TUC } & \text { Trades Union Congress }\end{array}$

